\section{Interspecific element incorporation in biogenic carbonates recapitulates phylogeny for diverse marine species}

ROBERT N. ULRICH ${ }^{1}$, MAXENCE GUILLERMIC ${ }^{1}$, JULIA CAMPBELL $^{1}$, ABBAS HAKIM ${ }^{1}$, RACHEL HAN ${ }^{1}$, SHAYLEEN SINGH ${ }^{1}$, JUSTIN D. STEWART ${ }^{2}$, CRISTIAN ROMÁN-PALACIOS ${ }^{3}$, HANNAH M. CARROLL ${ }^{1}$, ILIAN DECORTE $^{1}$, ROSALEEN E. GILMORE ${ }^{1}$, WHITNEY DOSS ${ }^{1}$, ARADHNA TRIPATI ${ }^{1}$, JUSTIN B. RIES ${ }^{4}$ AND ROBERT A

$$
\text { EAGLE }^{1}
$$

${ }^{1}$ University of California, Los Angeles

${ }^{2}$ Vrije Universiteit Amsterdam

${ }^{3}$ University of Arizona

${ }^{4}$ Northeastern University, Boston

Presenting Author: robu@g.ucla.edu

Elemental ratios in biogenic marine calcium carbonates are widely used in geobiology, environmental science, and paleoenvironmental reconstructions. It is generally accepted that the elemental abundance of biogenic marine carbonates reflects a combination of the abundance of that ion in seawater, the physical properties of seawater, the mineralogy of the biomineral, and the pathways and mechanisms of biomineralization. However, there is much yet unknown about the controls of trace and minor element incorporation in biominerals, and the literature is strongly focused on exploring this process in taxa that are typically used in paleoceanographic reconstruction, such as foraminifera, corals, and mollusks. Additionally, previous studies tend to focus on only one to a few species and elemental ratios at a time and use species collected from different geographic locations, impeding direct comparisons between species and their respective geochemistry, emphasizing the need for systematic studies surveying geochemical data across diverse species. Here we report measurements of a suite of 9 elemental ratios $(\mathrm{Li} / \mathrm{Ca}, \mathrm{B} / \mathrm{Ca}$, $\mathrm{Na} / \mathrm{Ca}, \mathrm{Mg} / \mathrm{Ca}, \mathrm{Zn} / \mathrm{Ca}, \mathrm{Sr} / \mathrm{Ca}, \mathrm{Cd} / \mathrm{Ca}, \mathrm{Ba} / \mathrm{Ca}, \mathrm{U} / \mathrm{Ca}$ ) in 18 benthic marine invertebrates spanning a range of biogenic carbonate polymorph mineralogies (low-Mg calcite, high-Mg calcite, aragonite, mixed mineralogy) and of phyla (including Mollusca, Echinodermata, Arthropoda, Annelida, Cnidaria, Chlorophyta, Rhodophyta) cultured at a single temperature $(25 \mathrm{oC})$ and a range of nominal $p \mathrm{CO} 2$ treatments $(400,600,900,2850 \mathrm{ppm})$. We use this dataset to explore the complex species- and biomineralization-pathway-specific controls over elemental partitioning in biogenic marine carbonates, the influence of internal $\mathrm{pH}$ regulation compared to external $\mathrm{pH}$ changes, and correlations of elemental partitioning with biocalcification responses to changes in seawater carbonate chemistry. The dataset also enables exploration of broad scale phylogenetic patterns of elemental partitioning across a wide taxonomic range of diverse species, which reveals associations between biogenic carbonate elemental chemistry and species relatedness.

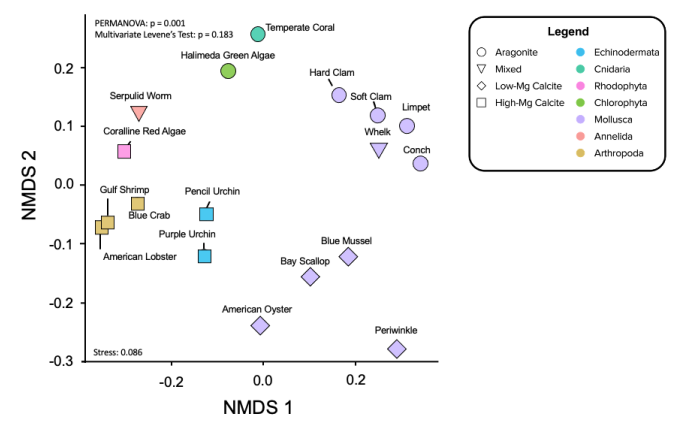

